\title{
South-east Asia's forest fires: blazing the policy trail
}

\author{
Ding Li Yong and KeLVin S.- H. PeH
}

Abstract Transboundary haze pollution as a result of indiscriminate land clearance by fire has significant health and economic impacts on member states of the Association of South-east Asian Nations (ASEAN). Meanwhile the impact of the associated carbon emissions, ecological disturbance and biodiversity loss extends well beyond South-east Asia. This is despite the fact there are relatively well-established mechanisms to combat forest fires, and policy-level solutions have existed on paper for years. Although the fires are mostly in Indonesian territory, the involvement of multiple hierarchies of stakeholders in Indonesia, Malaysia and Singapore adds complexity to the quest for lasting solutions. A more robust approach is required from the region's governments, especially in instilling accountability among large companies, and this is feasible without increasing political tensions within ASEAN. Indonesia's ratification of the Haze Agreement is a significant development but needs to be complemented with actions at the local (e.g. grassroot initiatives in forest protection, firefighting, policing of illegal clearance practices), national (e.g. centralizing ministrylevel control of forestry resources) and regional levels (e.g. implementing compliance mechanisms and legal standards to tackle haze and forest fires). Ultimately, actions to combat forest fires may also help secure the long-term conservation of biodiversity-rich peat swamps. Rather than being a source of discord, combating haze pollution could become Southeast Asia's defining environmental project.

Keywords Air pollution, biodiversity, fire, haze, peat swamp forest, socio-economics, South-east Asia

\section{Introduction}

T $\mathrm{n}$ mid June 2013 a state of emergency was declared 1 when air pollution in Singapore and Peninsular Malaysia reached hazardous levels, exceeding 750 on the Pollution Standards Index (Hussain \& Teo, 2013; Sim, 2013; National Environment Agency, 2014). The problem recurred, on a smaller scale, in 2014 during the dry period driven by the El Niño Southern Oscillation (Soeriaatmadja, 2014a). The haze is the most visible manifestation of the forest fires

Ding Li Yong Fenner School of Environment and Society, The Australian National University, Canberra, Australia

Kelvin S.-H. PeH (Corresponding author) Institute for Life Sciences, University of Southampton, Southampton SO17 1BJ, UK, and Conservation Science Group, University of Cambridge, CB2 3EJ, UK. E-mail kelvin.peh@gmail.com

Received 21 May 2014. Revision requested 28 August 2014.

Accepted 7 October 2014. First published online 22 December 2014. burning across the region (Quah, 2002), which cause significant damage to peat swamp and lowland dipterocarp forest ecosystems, including those in protected areas such as Giam-Siak Kecil (Fardah, 2014), Gunung Palung (Hiller et al., 2004) and Kutai National Park (van Nieuwstadt \& Sheil, 2005), with associated biodiversity loss and carbon emissions (Cochrane, 2002; Page et al., 2002; Gaveau et al., 2014).

Since the 1980 os forest fires and the resultant haze have served as an annual reminder of the failures of South-east Asian governments and institutions in preventing transboundary environmental problems. Monitoring and enforcement of a blanket ban on burning has proven difficult for the authorities, given that many forest fires are started in small-scale, slash-and-burn land-clearance activities (Varma, 2003), and thus the problem continues despite recognition of the damage, improved surveillance capabilities and fire-control knowledge, and a variety of policy approaches formulated over the decades. Here we review the underlying causes of South-east Asia's forest fires and haze, and discuss policy options that could help to provide a lasting redress of the problem.

\section{Causes of the haze}

Across South-east Asia land clearance using the slashand-burn method is common and is a leading cause of forest fires (Varma, 2003; Lohman et al., 2007). Much of the blame has been placed on oil palm plantations, including companies registered in Singapore and Malaysia, based on evidence from satellite imagery and ground investigations. Investigations have also increasingly highlighted the role played by mid-level independent plantation owners and smallholders using similar methods to clear land cheaply (Barber \& Schweithelm, 2000; Quah, 2002; Ekadinata et al., 2013). However, the fact that many large plantations also host smallholders makes it difficult to identify whether resident smallholders or the large corporate plantations are directly responsible for these clearance practices (Gaveau et al., 2014). To add further complexity to the problem the slash-and-burn technique is traditionally used by subsistence farmers to clear land in many parts of Indonesia (Varma, 2003).

Murdiyarso \& Adiningsih (2007) noted that forestry policy and practices endorsed by the authorities, especially the regulation of logging concessions, were partly to blame for exacerbating forest clearance in Indonesian Borneo. Together with natural bush fires, anthropogenic fires from land clearance are exacerbated by seasonal drought and the El Niño phenomenon, which drives dry conditions in the region 
(Heil \& Goldammer, 2001). In areas of peat swamp forest it can take months to extinguish underground fires in the highly combustible peat substrates (Page et al., 2002; Lohman et al., 2007), releasing significant amounts of carbon dioxide into the atmosphere (Gaveau et al., 2014).

\section{Impacts on biodiversity and ecosystems}

For a region recognized as a biodiversity hotspot (Myers et al., 2000) the loss of biodiversity in lowland dipterocarp and peat swamp forest ecosystems across Sumatra and Borneo has received little attention from the media or from decision makers at the highest levels of government, despite the evidence of forest destruction revealed by satellite images and on-the-ground surveys. Forest fires destroy or damage large numbers of trees, impeding natural succession and altering the floristic composition of surviving vegetation in the process (e.g. Slik et al., 2002), and triggering a positive feedback loop where fire-damaged forests are rendered more vulnerable to future fire events (Cochrane, 2002). Smoke from forest fires may also cause a reduction in productivity during dipterocarp masting events (Curran et al., 1999). Moreover, these fires damage and fragment degraded forest patches as well as pristine forests, reducing the extent, quality and value of remaining habitat for surviving wildlife. Some species may increase in abundance after fires but many suffer declines (e.g. Cleary, 2003), and surviving individuals are likely to perish if they are unable to find food, or fail to re-establish new territories in remnant habitats (Cochrane, 2002; Posa et al., 2011). In Sundaic South-east Asia many species affected already face threats such as habitat loss and hunting. These include a number of ecologically important species such as the orang-utan Pongo spp. (Wich et al., 2008), Asian elephant Elephas maximus, tiger Panthera tigris and various hornbill species (Bucerotidae). Furthermore, forest primary productivity may be affected, at least in the short term, given the reduced photosynthetic capacity arising from elevated levels of aerosol and atmospheric pollutants (Davies \& Unam, 1999; Kobayashi et al., 2005), with consequences for ecosystem functioning and processes. In the long term an altered landscape configuration resulting from completely burnt-over forests, with remaining forest patches occurring within a heavily degraded landscape matrix, is likely to hinder dispersal of wildlife. Increased accessibility of isolated wildlife populations to poachers further increases the risk of extirpation.

\section{Socioeconomic impacts}

Haze pollution has affected the health of South-east Asia's human population, with an estimated 70 million people regularly placed at risk of respiratory problems (Sastry, 2002;
Glover \& Jessup, 2006) as well as suffering indirect, longerterm effects from cancers linked to inhalation of smoke (Johnston et al., 2012; Marlier et al., 2013). The haze also has an economic impact on the region. 'Stay at home' advisories from national governments in the affected countries lead directly to loss of productivity and shrinking economies (Wong, 2013). Tourism, a major source of revenue for Singapore and Malaysia, is among the first industries to suffer; preliminary estimates indicate losses of c. USD 150 million in this sector, assuming an $8-10 \%$ decline in arrivals (Singh, 2013). Meanwhile, transport delays, accidents and cancellations as a result of poor visibility disrupt the shipping industry and airlines, leading to cascade effects on logistics for industries such as construction. Where areas of production forests and timber plantations are damaged by fire (Nicolas \& Beebe, 1999) the multi-million dollar logging industry also suffers from losses. Although there are no rigorous estimates of economic losses as a result of recent fire episodes, those generated during the 1990 s indicate that Singapore alone may have suffered losses of up to USD 290 million from one such episode (Glover \& Jessup, 2006).

\section{What has been done and why it has not worked}

There is a well-established framework to combat forest fires and it is pursued on multiple fronts to target the diverse stakeholders. In Indonesia, preventive measures have included incentives for agricultural stakeholders to clear land using alternative means instead of burning (Chang, 2013), disincentives such as fines, and awareness programmes targeting local communities. At a bilateral level Singapore and Malaysia, in collaboration with Indonesia, have coordinated mitigation efforts in the form of community outreach, development of a haze warning system, knowledge-sharing in peatland rehabilitation, and capacity building for fire managers and other grassroot-level personnel (Quah \& Varkkey, 2013). The Australian government has helped establish IndoFire, a real-time online tool for monitoring hotspots in Indonesia (IndoFire, 2014). At a regional level countries of the Association of South-east Asian Nations (ASEAN) affected by the haze have cooperated on fire-fighting and formulating policies to tackle the haze. For example, ministerial-level steering committee meetings have reviewed the 1997 Regional Haze Action Plan, resulting in the formulation of the 2002 ASEAN Agreement on Transboundary Haze Pollution (Nguitragool, 2011), a legally binding treaty ratified by all South-east Asian nations, most recently Indonesia.

A lasting solution to the haze problem remains elusive, however. The blanket ban on using fires to clear land in Indonesia (Glover \& Jessup, 2006) has limited effectiveness, given the deep-rooted nature of clearance practices among local farmers and smallholders. Furthermore, bringing recalcitrant plantation owners to justice has proved 
challenging because political will and enforcement capabilities are lacking, and the permitting process is beset by corruption at multiple levels (Hussain, 2013a).

Another problem lies in divergent policies and actions resulting from the involvement of multiple ministries (Forestry, Agriculture, Home and Environment), and provincial and district governments in tackling Indonesia's forest fires, each with different agendas and resource limitations (Glover \& Jessup, 2006; Varkkey, 2008). The situation is further complicated by problems with decentralization leading to increased control of forestry resource regulations by the central government in Jakarta, resulting in district governments being in conflict with the forestry ministry (Varkkey, 2008). Problems of perception also exist. The fact that forest fires are largely confined to Sumatra, Borneo and remote West Papua may create a flawed perception among Indonesian legislators in Jakarta that these are localized natural disasters (Pereira, 2013) and the need for regional cooperation through ASEAN is an irrelevant constraint.

National sovereignty and nationalist sentiments add another barrier by limiting cross-border cooperation between Indonesia and neighbouring countries (Varkkey, 2008). Despite pressure from other ASEAN governments, earlier ratification of the Haze Agreement was blocked repeatedly by powerful parties in the Indonesian parliament and regional authorities, citing nationalist concerns and a perceived lack of credibility (Nguitragool, 2011). A bilateral collaboration between Singapore and the provincial government of Jambi (Indonesia) to support fire-fighting and mitigation efforts was unilaterally terminated by Indonesia in 2011, largely based on nationalist considerations (Toh, 2013). A similar project between Malaysia and the Riau provincial government also ended in impasse (Quah \& Varkkey, 2013).

Twelve years after the Transboundary Haze Agreement was conceived, Indonesia ratified the agreement on 16 September 2014, the last ASEAN member state to do so (Soeriaatmadja, 2014b). The 1995 ASEAN Cooperation Plan on Transboundary Pollution had limited effect in preventing forest fires; it focused on man-made fires but failed to make explicit the sensitive domestic issues in Indonesia that cause the fires, particularly illegal logging and unsustainable land use (Nguitragool, 2011). The continuation of the haze crisis is a timely reminder of ASEAN's weakness in finding solutions to cross-border environmental problems, given its style of regional engagement, noninterference and consensus-building, emphasizing national sovereignty (Nguitragool, 2011).

\section{Charting the way ahead}

Notwithstanding the challenges, a lasting redress is possible. The haze crisis presents an opportunity for ASEAN to review its engagement strategy and implement appropriate reforms, which we recommend should include the following:

\section{Local empowerment}

Bottom-up initiatives need to be encouraged through grassroots involvement to cultivate local ownership of sustainable development and forest protection, especially at the village (desa) and district (kecematan) levels. For example, within the affected provinces in Sumatra and Kalimantan, local community networks could be formed to disseminate information on the location of hotspots and coordinate evacuation and fire-fighting efforts.

Such efforts have been impeded by the lack of public access to complete, up-to-date concession maps, making it difficult for the public to exert pressure on errant companies or individuals. At the ASEAN sub-regional ministerial meeting on 17 July 2013 a conditional agreement was made to share updated concession maps between governments but not with the public (Hussain, 2013b). Crowd-sourcing by means of citizen mapping could be a potential solution to the problem, with teams of amateur mappers and volunteers working with simple, open-source tools such as Google Map Maker (Google, Mountain View, USA) to chart forest boundaries, hotspots and concessions. Although there may be limitations in the logistics needed to centralize and integrate the data collected, such collaboratively compiled maps could be circulated to the wider community, authorities and local NGOs. By linking afflicted areas with the plantation companies involved, a higher level of corporate accountability could be expected, or at least culprits could be identified.

\section{National-level consensus and coordination}

Indonesia remains integral in providing the impetus to tackle haze pollution. Despite the former Indonesian President Susilo Bambang Yudhoyono's unprecedented apology to neighbouring countries during the 2013 haze episode (Hussain, 2013c), more needs to be done to impress upon Indonesia's political elite and legislators that a solution to the problem is needed without delay. A number of positive steps for forest conservation were pursued during President Yudhoyono's tenure, in particular a moratorium on deforestation (Murdiyarso et al., 2011), a national action plan to cut greenhouse gas emissions (MNDP/NDPA, 2011), and the establishment of a national REDD+ (Reducing Emissions from Deforestation and forest Degradation) plan and agency (Presidential Regulation No. 62/2013). The launch of the One Map initiative in 2011, an on-going effort to consolidate various maps into a standardized version, will also help synchronize land concession information 
between various stakeholder ministries (Samadhi, 2013) and will facilitate the government's efforts to tackle forest fires. Indonesia could further take the lead by aligning environmental protection with other high-priority issues such as trade and foreign affairs; this would remind mid-level decision makers that environmental problems are serious and need to be tackled, in contrast with the current ASEAN practice of separating trade from environmental concerns.

Indonesia is still adapting to a decentralized political system, with provincial governments unable to respond as swiftly or with adequate resources to tighten enforcement or deploy fire-fighting resources. Thus, the central government in Jakarta would need to exercise greater political resolve to ensure that national environmental regulations take precedence over local rules (Ibrahim \& Hussain, 2014). It remains to be seen how far the administration of the new president, Joko Widodo, who was inaugurated on 20 October 2014, will take these measures and implement tighter regulations to tackle Indonesia's environmental problems in general and the haze and forest fires in particular.

\section{Regional cooperation}

The potential of a fully integrated approach by ASEAN in tackling transboundary environmental problems cannot be underestimated. Past failures in addressing the haze problem and the recent outrage in the affected countries could provide the impetus for future institutional reform, and ASEAN will need to review its model of soft engagement in tackling transboundary problems, and establish solidarity across member states in addressing these problems. Indonesia has made significant progress by ratifying the Haze Agreement and implementing its plan of action in dealing with forest fires. ASEAN needs to ensure that the agreement is legally binding, with long-term monitoring and compliance mechanisms in place.

In the interest of better ASEAN integration it is essential to harmonize legal standards across the region and to strengthen legal frameworks for the region. The rule of law should be the foundation of a framework for executing ASEAN's environmental projects, guiding the interactions between member states when environmental crises arise. Under the Rio Declaration on Environment and Development, states are responsible for preventing activities under their jurisdiction from causing damage to the environment of other states (Koh \& Ewing-Chow, 2013). As a last resort, international arbitration, an established approach to settle disputes among member states in the past, should be sought. Given that Indonesia and Malaysia hold the largest expanses of peat swamp forests in South-east Asia, the onus is on both countries to designate these ecologically significant carbon sinks as protected areas, which could also improve ASEAN's credibility internationally.

Singapore's attempt to adopt extraterritorial regulations and explore possibilities for legal action against companies responsible for environmental pollution (Toh, 2013) has culminated in the Transboundary Haze Pollution Act 2014 (Chua, 2014). Although no prosecutions have yet been made, those responsible for haze-causing fires on their land may be subject to lawsuits and loss of investment (Feng, 2014a). Although there are challenges involved in sharing the information needed for prosecutions, particularly concession maps, some progress has been made in the adoption of the ASEAN Sub-Regional Haze Monitoring System proposed by Singapore, and more recently the finalization of a new memorandum of understanding between Singapore and the Jambi provincial government (Feng, 2014b).

Singapore and Malaysia need to update their in-country cost analyses of the haze situation on a regular basis and seek compensation from the companies prosecuted by the Indonesian government. Finally, richer member states such as Singapore could invest in better forest protection by supporting REDD+ policies in Indonesia.

\section{International outreach}

Besides action at various institutional levels, responsible consumers can influence the behaviour of palm oil companies by demanding environmentally sustainable products (Mahbubani, 2013). Some of the biggest companies in the palm oil and paper industries have committed to zero deforestation and sustainable production (e.g. Wilmar International, 2013), and other companies operating in the region must follow suit. Individuals and international NGOs can harness the global reach of social media to publicize the burning issues underlying the haze and commit to boycotting companies implicated, while ensuring more responsible companies have financial incentives to adopt best practices and green certification.

Applying these recommendations will be challenging and will require the collective will of institutions in South-east Asia. For the region as a whole, however, this is a crisis with an opportunity: the haze could become an impetus for collaboration within ASEAN to address the challenges of biodiversity loss and environmental protection. Recent political movements such as the first Indonesian government audit of plantation companies in August 2014 (Soeriaatmadja, 2014C) and the merging of the Indonesian Forestry and Environment Ministries into one entity in October 2014 (Hussain, 2014) may be cause for optimism that broader efforts to tackle forest fires in the region are gaining momentum; and the ratification of the ASEAN haze pact by Indonesia may indicate 
that regional action on tackling environmental issues is imminent. Although it is still too early to assess the efficacy of these measures we are confident that a growing frustration at the annual forest fires, combined with wider awareness of environmental and biodiversity conservation among the general public, partly as a result of social media, will maintain the momentum of these actions.

\section{References}

Barber, C.V. \& Schweithelm, J. (20oo) Trial by Fire: Forest Fires and Forestry Policy in Indonesia's Era of Crisis and Reform. World Resources Institute, Washington, DC, USA.

ChanG, R. (2013) Right way of farming is long-term solution: PM Lee. Http://news.asiaone.com/News/Haze/Story/

A1Story20130624-432069.html [accessed 24 September 2014].

Chua, G. (2014) Haze law passed; fines may go up if necessary. The Straits Times. Http://news.asiaone.com/news/singapore/hazelaw-passed-fines-may-go-if-necessary [accessed 6 August 2014].

Cleary, D.F. (2003) An examination of scale of assessment, logging and ENSO-induced fires on butterfly diversity in Borneo. Oecologia, 135, 313-321.

Cochrane, M.A. (2002) Spreading Like Wildfire-Tropical Forest Fires in Latin America and the Caribbean: Prevention, Assessment and Early Warning. United Nations Environment Programme, Mexico City, Mexico.

Curran, L.M., Caniago, I., Paoli, G.D., Astianti, D., Kusneti, M., Leighton, M. et al. (1999) Impact of El Niño and logging on canopy tree recruitment in Borneo. Science, 286, 2184-2188.

Davies, S.J. \& UnAM, L. (1999) Smoke-haze from the 1997 Indonesian forest fires: effects on pollution levels, local climate, atmospheric $\mathrm{CO}_{2}$ concentrations, and tree photosynthesis. Forest Ecology and Management, 124, 137-144.

Ekadinata, S., van Noordwijk, M., Budidarsono, S. \& Dewi, S. (2013) Hot Spots in Riau, Haze in Singapore: The June 2013 Event Analysed. ASB Policybrief No. 33. ASB Partnership for the Tropical Forest Margins, Nairobi, Kenya.

FARDAH (2014) Racing against time to save Riau's biosphere reserve from fires. Antara News. Http://www.antaranews.com/en/news/ 93083/racing-against-time-to-save-riaus-biosphere-reserve-fromfires [accessed 20 May 2014].

FenG, Z. (2014a) Transboundary haze bill 'not shrouded in secrecy'. The Straits Times. Http://news.asiaone.com/news/singapore/ transboundary-haze-bill-not-shrouded-secrecy [accessed 21 May 2014].

FENG, Z. (2014b) Singapore frustrated at slow pace in tackling haze. The Straits Times. Http://www.straitstimes.com/st/print/2234913 [accessed 3 April 2014].

Gaveau, D.L.A., Salim, M.A., Hergoualc'h, K., Locatelli, B., SloAn, S., Wooster, M. et al. (2014) Major atmospheric emissions from peat fires in Southeast Asia during non-drought years: evidence from the 2013 Sumatran fires. Scientific Reports, 4, 6112.

Glover, D. \& Jessup, T. (eds) (2006) Indonesia's Fires and Haze: The Cost of Catastrophe. International Development Research Centre, Ottawa, Canada.

Heil, A. \& Goldammer, J.G. (2001) Smoke-haze pollution: a review of the 1997 episode in Southeast Asia. Regional Environmental Change, 2, 24-37.

Hiller, M.A., Jarvis, B.C., Lisa, H., Paulson, L.J., Pollard, E.H.B. \& STANley, S.A. (2004) Recent trends in illegal logging and a brief discussion of their causes: a case study from Gunung Palung
National Park, Indonesia. Journal of Sustainable Forestry, 19, 181-212.

Hussain, Z. (2013a) Haze update: rampant corruption fanned forest fires, say watchdogs. The Straits Times. Http://www.straitstimes. com/archive/tuesday/st/print/1237423 [accessed 25 June 2013].

Hussain, Z. (2013b) Jakarta's info law forbids sharing of maps. The Straits Times. Http://www.straitstimes.com/breaking-news/se-asia/ story/haze-update-rampant-corruption-fanned-forest-firessay-watchdogs-2013062 [accessed 19 July 2013].

Hussain, Z. (2013c) Indonesian leader says sorry for haze. The Straits Times. Http://news.asiaone.com/News/AsiaOne+News/Asia/Story/ A1Story20130626-432472.html [accessed 29 June 2013].

Hussain, Z. (2014) Indonesia to merge forestry, environment ministries. The Straits Times. Http://www.asianewsnet.net/ Indonesia-to-merge-forestry-environment-ministries-66414.html [accessed 24 October 2014].

Hussain, Z. \& Teo, C.W. (2013) Emergency declared in 2 Johor districts. The Straits Times. Http://www.stasiareport.com/the-bigstory/asia-report/malaysia/story/emergency-declared-2-johordistricts-20130624 [accessed 17 July 2013].

Iвrahim, Z. \& Hussain, Z. (2014) Jokowi vows to get tough with haze offenders. The Straits Times. Http://www.straitstimes.com/the-bigstory/joko-widodo/story/jokowi-vows-get-tough-haze-offenders20140822 [accessed 22 August 2014].

IndoFire (2014) IndoFire Map Service. Http://indofire.landgate.wa. gov.au [accessed 25 September 2014].

Johnston, F.H., Henderson, S.B., Chen, Y., Randerson, J.T., Marlier, M., DeFries, R.S. et al. (2012) Estimated global mortality attributable to smoke from landscape fires. Environmental Health Perspectives, 120, 695-701.

Kobayashi, H., Matsunaga, T. \& Hoyano, A. (2005) Net primary production in Southeast Asia following a large reduction in photosynthetically active radiation owing to smoke. Geophysical Research Letters, 32, Lo2403.

Kон, T. \& EwING-Chow, M. (2013) Insight: the transboundary haze and the international law. The Jakarta Post. Http://www. thejakartapost.com/news/2013/06/27/insight-the-transboundaryhaze-and-international-law.html [accessed 17 July 2013].

Lohman, D.J., BICKFORD, D. \& SodHi, N.S. (2007) The burning issue. Science, $316,376$.

Mahbubani, K. (2013) To do good, be shrewd. The Straits Times. Http:// www.straitstimes.com/st/print/1300395 [accessed 17 July 2013].

Marlier, M.E., DeFries, R.S., Voulgarakis, A., Kinney, P.L., Randersen, J.T., Shindell, D.T. et al. (2013) El Niño and health risks from landscape fire emissions in southeast Asia. Nature Climate Change, 3, 131-136.

MNDP/NDPA (Ministry of National Development Planning/ National Development Planning Agency) (2011) Guideline for Implementing Greenhouse Gas Emission Reduction Action Plan. Http://www.paklim.org/wp-content/uploads/downloads/2012/05/ Guideline-for-the-implementation-of-GHG-emission-reductionaction-plan.pdf [accessed 23 September 2014].

Murdiyarso, D. \& Adiningsin, E.S. (2007) Climate anomalies, Indonesian vegetation fires and terrestrial carbon emissions. Mitigation and Adaptation Strategies for Global Change, 12, 101-112.

Murdiyarso, D., Dewi, S., Lawrence, D. \& Seymour, F. (2011) Indonesia's Forest Moratorium: A Stepping Stone to Better Forest Governance? Working Paper 76. CIFOR, Bogor, Indonesia.

Myers, N., Mittermeier, R.A., Mittermeier, C.G., Da Fonseca, G.A.B. \& Kent, J. (2000) Biodiversity hotspots for conservation priorities. Nature, 403, 853-858.

National Environment Agency (2014) PSI. Http://app2.nea.gov. $\mathrm{sg} /$ anti-pollution-radiation-protection/air-pollution-control/psi [accessed 23 September 2014]. 
NGuitragool, P. (2011) Negotiating the haze treaty. Asian Survey, 51, 356-378.

Nicolas, M.V.J. \& Beebe, G.S. (1999) Fire Management in the Logging Concessions and Plantation Forests of Indonesia. European Union, German Agency for Technical Cooperation and Ministry of Forestry and Estate Crops, Indonesia.

Page, S.E., Siegert, F., Rieley, J.O., Boehm, H.-D.V., Jaya, A. \& Limin, S. (2002) The amount of carbon released from peat and forest fires in Indonesia during 1997. Nature, 420, 61-65.

Pereira, D. (2013) Indonesia's mindset on haze casts pall on ties. The Straits Times. Http://www.straitstimes.com/the-big-story/the-hazesingapore/story/indonesias-mindset-haze-casts-pall-ties-20130622 [accessed 17 July 2013].

Posa, M.R., Wijedasa, L.S. \& Corlett, R.T. (2011) Biodiversity and conservation of tropical peat swamp forests. BioScience, 61, 49-57.

QuAh, E. (2002) Transboundary pollution in Southeast Asia: the Indonesian fires. World Development, 30, 429-441.

Quah, E. \& VARKKey, H. (2013) The political economy of transboundary pollution: mitigation of forest fires and haze in Southeast Asia. In The Asian Community: Its Concepts and Prospects (ed. S. Hayashihana), pp. 323-358. Soso Sha, Tokyo, Japan.

Samadi, N. (2013) Indonesia ONE MAP: Assuring Better Delivery of National Development Goals. Http://www.geospatialworldforum. org/2013/presentation/Nirata\%2oSamdhi.pdf [accessed 23 September 2013].

SASTRY, N. (2002) Forest fires, air pollution and mortality in South-east Asia. Demography, 39, 1-23.

SIM, W. (2013) PSI hits 88 as fires in Sumatra bring haze. The Straits Times. Http://www.straitstimes.com/the-big-story/the-hazesingapore/story/psi-hits-88-fires-sumatra-bring-haze-20130617? page $=10$ [accessed 17 July 2013].

SINGH, P.P. (2013) Businesses hit as Singapore haze moves in. BBC News. Http://www.bbc.co.uk/news/business-22999205 [accessed 17 July 2013].

Slik, J.F., Verburg, R.W. \& Keßler, P.J. (2002) Effects of fire and selective logging on the tree species composition of lowland dipterocarp forest in East Kalimantan, Indonesia. Biodiversity and Conservation, 11, 85-98.

Soeriantmadja, W. (2014a) Jakarta takes steps to curb forest fires. The Straits Times. Http://www.stasiareport.com/the-big-story/asiareport/indonesia/story/jakarta-takes-steps-curb-forest-fires-20140614 [accessed 14 June 2014].
Soeriantmadja, W. (2014b) Singapore welcomes Jakarta's move to ratify haze pact. The Straits Times. Http://www.straitstimes.com/ the-big-story/asia-report/indonesia/story/singapore-welcomesjakartas-move-ratify-haze-pact-20140917 [accessed 17 September 2014].

SoeriaAtmadja, W. (2014c) Indonesia warns 15 plantation firms for playing with fire. The Straits Times. Http://www.straitstimes. com/the-big-story/asia-report/indonesia/story/indonesia-warns-15plantation-firms-playing-fire-20141011 [accessed 11 October 2014].

Toн, E. (2013) Singapore looking into laws to deal with firms behind haze. The Straits Times. Http://news.asiaone.com/News/Haze/ Story/A1Story20130709-435788.html [accessed 17 July 2013].

van Nieunstadt, M.G. \& Sheil, D. (2005) Drought, fire and tree survival in a Borneo rain forest, East Kalimantan, Indonesia. Journal of Ecology, 93, 191-201.

VARKKEY, H.M. (2008) Indonesian perspectives on managing the ASEAN haze. Sarjana, 24, 83-101.

VARMA, A. (2003) The economics of slash and burn: a case study of the 1997-1998 Indonesian forest fires. Ecological Economics, 46, 159-171.

Wich, S.A., Meijaard, E., Marshall, A.J., Husson, S., Ancrenaz, M., LACY, R.C. et al. (2008) Distribution and conservation status of the orang-utan (Pongo spp.) on Borneo and Sumatra: how many remain? Oryx, 42, 329-339.

Wilmar International (2013) No Deforestation, No Peat, No Exploitation Policy. Http://www.wilmar-international.com/wpcontent/uploads/2012/11/No-Deforestation-No-Peat-No-ExploitationPolicy.pdf [accessed 20 May 2013].

WonG, S.Y. (2013) Haze may impact economic growth if condition does not improve: economists. Channel News Asia. Http://www. channelnewsasia.com/news/specialreports/mh37o/news/haze-mayimpact-economic/720064.html [accessed 21 June 2013].

\section{Biographical sketches}

DING LI YONG is investigating how biodiversity surrogates can be used to improve conservation outcomes. He is also interested in tropical bird communities, bird migration, and conservation in South-east Asia. Kelvin Peh's research interests lie in tropical forest ecology, ecosystem services and biodiversity conservation. 